J. Clin. Chem. Clin. Biochem.

Vol. 16, 1978, pp. 539-541

\title{
Urinary Isoamylases in Juvenile Diabetics
}

\author{
By J. Kamarýt, J. Stejskal and Libuše Osičková
}

From the Pediatric Research Institute (Head As. Prof. Dr. O. Bilek, CSc.), Brno, ČSSR and IInd Pediatric Department, Medical Faculty (Head As. Prof. Dr. J. Stejskal, CSc.), J. E. Purkyně University, Brno, ĆSSR

(Received December 28, 1977/May 27, 1978)

Summary: An anomalous ratio of salivary to pancreatic amylase activities has been observed in urine from juvenile diabetics. Decreased pancreatic amylase activity in urine from these subjects appears to be a characteristic trait.

\section{Isoamylasen im Harn bei juvenilen Diabetikern}

Zusammenfassung: Im Harn juveniler Diabetiker wurde ein von Gesunden abweichendes Verhältnis von Speichelzu Pankreasamylase-Aktivität beobachtet. Die erniedrigte Pankreasamylase-Aktivität im Harn gesunder Diabetiker scheint ein für diese Patienten charakteristisches Merkmal zu sein.

\section{Introduction}

Ben Abdeljlil \& Palla (1) were the first to describe the action of insulin on the biosynthesis of $\alpha$-amylase $(\alpha-1,4$-glucan 4-glucanohydrolase EC 3.2.1.1) and some other enzymes of rat pancreas. Couture et al. (2) confirmed these findings but they did not show any direct action of insulin on secretion and synthesis in vitro. Söling et al. (3) obtained similar results and supposed that the insulin regulates amylase synthesis in the pancreas mainly at the level of transcription. Exocrine pancreatic function has been shown to be often impaired in diabetic subjects. Chey et al. (4) reported low amylase contents in duodenal juice from juvenile diabetics. The reported findings of reduced amylase activity in duodenal juice are convincing and indicate an impaired exocrine pancreatic function. Unfortunately amylase activity determination in duodenal juice did not yield reliable results, and it is difficult to obtain this biological material, particularly from children. We have therefore tried to estimate the pancreatic amylase level from the ratio of salivary to pancreatic amylase activities in urine from healthy controls and juvenile diabetics.

\section{Materials and Methods}

\section{Subjects}

We examined 20 children - juvenile diabetics between ages 9 and 16 years and a control group of 20 heal thy children of the same average age. The sick children were admitted to the hospital with the diagnosis of various states of decompensated juvenile diabetes mellitus, with polyuria, polydipsia and weight loss, and all had elevated blood glucose levels and impaired glucose tolerance. In five individuals from the group of randomly selected juvenile diabetics the renal clearance of total, salivary and pancreatic amylase was also determined. As a control, we examined amylase renal clearance in ten young adults (range 19 to 36 years). Skude (5) reported recently that the amylase clearances values in young healthy adults did not exhibit any significant differences in comparison with those found in healthy children (range $6-16$ years).

\section{Procedure}

Urine and sera collected for amylase activity determinations were examined on the same day, or after storage at $4{ }^{\circ} \mathrm{C}$ for 3-6 days. During this time there are no changes in the amylase activities.

Salivary and pancreatic isoamylases were separated by means of agar gel electrophoresis in veronal buffer $\mathrm{pH}$ 8.4. After detection and iodine staining, it is possible to evaluate the salivary and pancreatic amylase activities as relative fractions by densitometry $(600 \mathrm{~nm})$ of the zymograms. The method has been already reported elsewhere (6). The total amylase activities in blood serum and urine were determined by the method of Street \& Close (7). Creatinine clearances were determined as an index of glomerular filtration rate.

\section{Results}

Densitometry of urinary amylase zymograms from 20 heal thy subjects showed mean values of 0.363 and 0.637 for the relative activities of salivary and pancreatic amylases, respectively (tab. 1). In the group of 20 juvenile diabetics the relative activities of salivary and pancreatic isoamylases represented average values of 0.540 and 0.460 , respectively. In all examined juvenile diabetics the relative pancreatic isoamylase activity 
Tab. 1. Salivary and pancreatic isoamylases in urine and blood serum from hcal thy subjects and juvenile diabetics.

\begin{tabular}{|c|c|c|c|c|c|c|c|}
\hline & \multicolumn{3}{|l|}{ Urine } & \multicolumn{4}{|c|}{ Serum . } \\
\hline & Salivary amylase & Pancreatic a & ylase & \multirow{2}{*}{\multicolumn{2}{|c|}{$\frac{\text { Total amylase }}{\text { Street-Close U/1 }}$}} & Salivary amylase & Pancreatic amylase \\
\hline & \multicolumn{3}{|l|}{ Activity fractions } & & & \multicolumn{2}{|l|}{ Activity fractions } \\
\hline & \multicolumn{4}{|c|}{ Heal thy controls } & \multicolumn{3}{|l|}{$\mathrm{n}=\mathbf{2 0}$} \\
\hline \multirow[t]{2}{*}{$\bar{\lambda} \pm s$} & $\begin{array}{l}0.363 \\
0.083\end{array}$ & $\begin{array}{l}0.637 \\
0.083\end{array}$ & & $\begin{array}{r}182 \\
43\end{array}$ & & $\begin{array}{l}0.514 \\
0.153\end{array}$ & $\begin{array}{l}0.486 \\
0.150\end{array}$ \\
\hline & \multicolumn{7}{|c|}{ Juvenile diabetics } \\
\hline \multirow[t]{2}{*}{$\bar{x} \pm s$} & $\begin{array}{l}0.540 \\
0.066\end{array}$ & $\begin{array}{l}0.460 \\
0.073\end{array}$ & & $\begin{array}{r}213 \\
63\end{array}$ & & $\begin{array}{l}0.708 \\
0.107\end{array}$ & $\begin{array}{l}0.292 \\
0.112\end{array}$ \\
\hline & $P<0.005$ & $P<0.005$ & & $\mathbf{P}>$ & & $P<0.005$ & $P<0.005$ \\
\hline
\end{tabular}

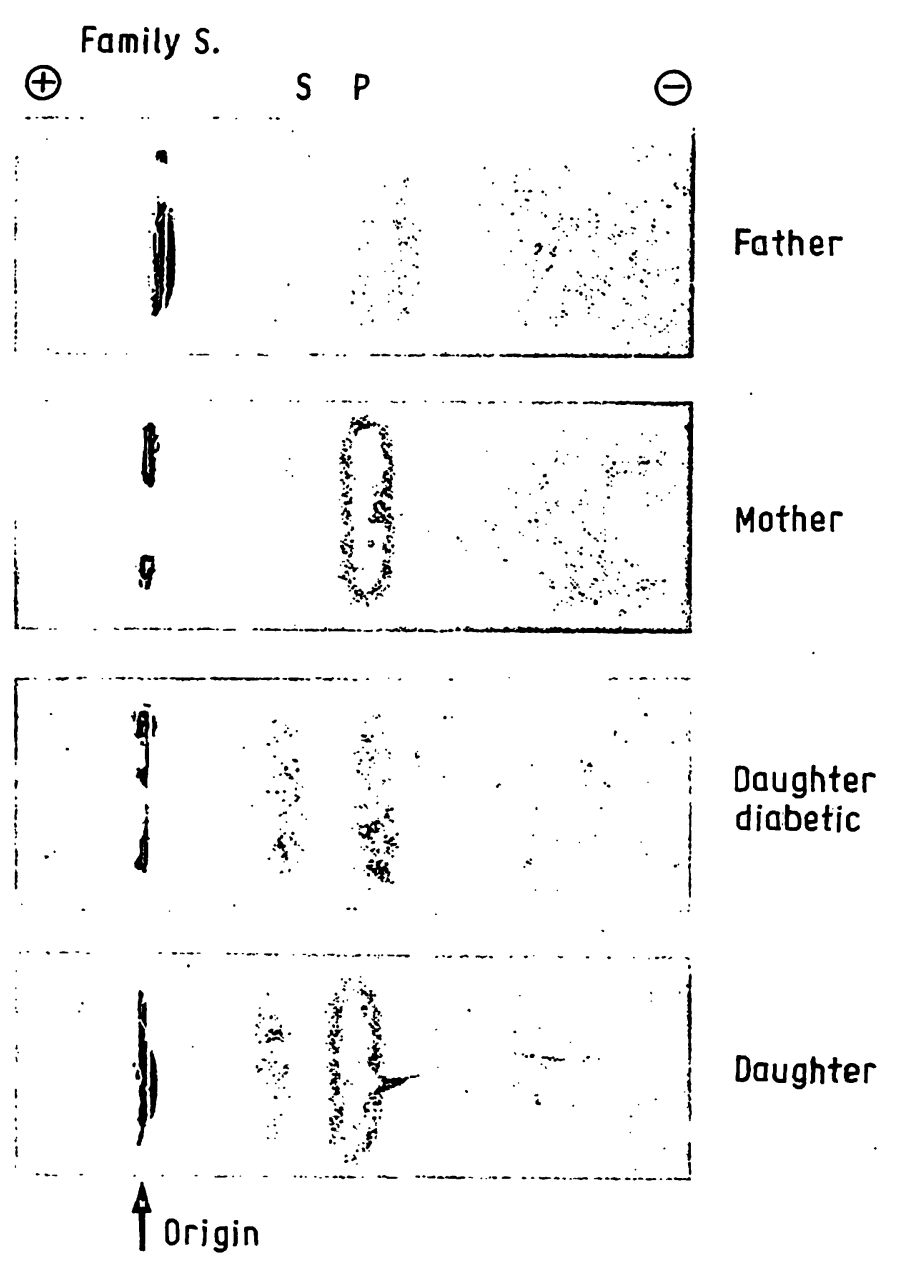

Fig. 1. Zymogram showing isoamylases in urine from members of a family with juvenile diabetes. Isoamylase activities as relative fractions.

Salivary amylase (S)

$\begin{array}{ll}\text { father } & 0.155 \\ \text { mother } & 0.214 \\ \text { propositus } & 0.503 \\ \text { healthy sister } & 0.368\end{array}$

Pancreatic amylase $(\mathrm{P})$

$0.405+0.440$

0.786

0.497

0.632

Note: father carries the genetically determined heterozygous variant of amylase polymorphism with two pancreatic fractions (Amy LAlA Amy 2A2B). fraction in urine was lower than in nondiabetic subjects $(P<0.005)$. Though there were no significant differences between total serum amylase activities in diabetics and healthy controls $(P>0.10)$, the ratio of both isoamylase activities were still significantly shifted $(P<0.005)$ due to the higher activity of salivary and the lower activity of pancreatic isoamylase. The anomalous salivary to pancreatic amylase ratio in urine from diabetics was very marked especially in comparison with zymograms of the diabetic's parents or his healthy sister, respectively (fig. 1). The mean values of total and particularly pancreatic amylase clearances in juvenile diabetics are considerably reduced in comparison with the corresponding values in the nondiabetic controls $(P<0.01 ; P<0.002)$ (tab. 2). The salivary amylase clearance in juvenile diabetics was not significantly changed $(P>0.10)$. The values of total amylase clearance to creatinine clearance ratios did not indicate any differences between the group of juvenile diabetics and healthy controls $(P>0.10)$. Small but not statistically significant differences were obtained between the ratios of salivary amylase clearance to creatinine clearance, and the ratios of pancreatic amylase clearance to creatinine clearance $(P>0.10)$. However the wide range of all these ratios are evident in the group of juvenile diabetics.

\section{Discussion}

In healthy subjects the average ratio of salivary to pancreatic amylase activities appears admirably stable: in blood serum approximately $1: 1$, in urine $1: 2$. Higher pancreatic isoamylase activity in urine is due to the higher renal clearance of this isoenzyme (8). The regular lower activities of pancreatic amylase in the urine of juvenile diabetics, due to the lower production of the enzyme by the pancreas, may be related to either the partial or total deficiency of insulin secretion in this disorder (9). 
Tab. 2. Renal clearances of total, salivary and pancreatic amylase and their ratio to creatinine clearance in heal thy young adults and juvenile diabetics.

\begin{tabular}{|c|c|c|c|c|c|c|}
\hline & \multicolumn{2}{|c|}{ Total amylase } & \multicolumn{2}{|c|}{ Salivary amylase } & \multicolumn{2}{|c|}{ Pancreatic amylase } \\
\hline & $\begin{array}{l}\text { Clearance } \\
(\mu \mathrm{l} / \mathrm{s})\end{array}$ & $\begin{array}{l}\text { Clearance } \\
\text { ratio }\end{array}$ & $\begin{array}{l}\text { Clearance } \\
(\mu 1 / s)\end{array}$ & $\begin{array}{l}\text { Clearance } \\
\text { ratio }\end{array}$ & $\begin{array}{l}\text { Clearance } \\
(\mu 1 / s)\end{array}$ & $\begin{array}{l}\text { Clearance } \\
\text { ratio }\end{array}$ \\
\hline & \multicolumn{6}{|c|}{ Healthy controls $n=10$} \\
\hline \multirow[t]{2}{*}{$\bar{x} \pm s$} & $\begin{array}{r}41.3 \\
9.7\end{array}$ & $\begin{array}{l}0.0198 \\
0.0061\end{array}$ & $\begin{array}{r}25.7 \\
5.3\end{array}$ & $\begin{array}{l}0.0124 \\
0.0034\end{array}$ & $\begin{array}{l}59.3 \\
14.8\end{array}$ & $\begin{array}{l}0.0284 \\
0.0082\end{array}$ \\
\hline & \multicolumn{6}{|c|}{ Juvenile diabetics $n=5$} \\
\hline \multirow[t]{2}{*}{$\bar{x} \pm s$} & $\begin{array}{r}22.8 \\
9.2\end{array}$ & $\begin{array}{l}0.0203 \\
0.0106\end{array}$ & $\begin{array}{l}20.2 \\
10.3\end{array}$ & $\begin{array}{l}0.0175 \\
0.0091\end{array}$ & $\begin{array}{r}28.8 \\
7.5\end{array}$ & $\begin{array}{l}0.0268 \\
0.0121\end{array}$ \\
\hline & $P<0.01$ & $P>0.10$ & $P>0.10$ & $P>0.10$ & $P<0.002$ & $P>0.10$ \\
\hline
\end{tabular}

The results obtained in our laboratory agree with the above mentioned findings reported for experiments in animals $(1,2,3)$, i. e., that the insulin plays a permissive role in pancreatic amylase synthesis.

The decreased amylase production by pancreas, together with higher amylase secretion from salivary glands (compensatory mechanism?), results in adjustment of the total blood serum amylase activity within a normal range in juvenile diabetics. The shifted isoamylase ratio in urine appears as a consequence of

\section{References}

1. Ben Abdeljlil, A., Palla, J. C. \& Desnuelle, P. (1965), Biochem. Biophys. Res. Commun. 18,71-75.

2. Couture, Y., Dunnigan, J. \& Morisset, J. (1972), Scand. J. Gastroenterol. 7, 257-263.

3. Söling, H. D. \& Unger, K. O. (1972), Eurơp. J. Clin. Invest. 2, 199-212.

4. Chey, W. Y., Shay, H. \& Shuman, C. R. (1963), Ann. Intern. Med. 59, 812.

5. Skude, D. (1975), Scand. J. Gastroenterol. 10, 577-584. these mechanisms. Even if the changed ratio of salivary to pancreatic amylase in urine from juvenile diabetics appears as a characteristic trait, the proper cause of this phenomenon remains unclear. Further investigations aimed to elucidate this problem are desirable.

\section{Acknowledgement}

We are greatly indebted to Mrs. Ludmila Vostrejšová and Helga Mašaráková for skilful technical assistance.

6. Kamarýt, J. \& Laxová, R. (1965), Humangenetik, 1, 579-586.

7. Street, H. \& Close, J. D. (1956), Clin. Chim. Acta 1, 256268.

8. Kamarýt, J. (1969), this Journal 7, 51-52.

9. Lestradet, H., Besse, J., Billaud, L., Battistelli, F., Tric, F. \& Lestradet, F. (1976), La Nouvelle Presse Médicale, 23, 2297-2298.
J. Kamarýt, Ph. D., Pediatric Research Institute, Černopolní 9, ČS 66262 Brno, ČssR 


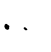

。 